\title{
Impact of alcohol consumption on the health of pregnant women and their children - a review of studies
}

\author{
Wpływ picia alkoholu na zdrowie kobiet w ciąży i ich dzieci - przegląd badań
}

1 Department of Cancer Prevention, Medical University ofWarsaw, Warsaw, Poland

${ }^{2}$ Institute of Psychiatry and Neurology, Warsaw, Poland

Correspondence: Marta Dulęba, Podłazie 3, 26-140 Łączna, Poland, e-mail: marta.reczek@op.pl

\begin{abstract}
Introduction: Alcohol is one of the strongest teratogens. Since the 1960s, information campaigns have been conducted to address its harmful effect and promote quitting drinking, especially by pregnant women. The aim of this paper includes a review of literature concerning research on alcohol use by pregnant women and learning about their knowledge of the detrimental effects of ethanol on the health of themselves and their unborn children. This paper shall also assess social campaigns devoted to informing this group of women about the harmful effects of alcohol consumption. Description of state of knowledge: The review explicitly confirmed data on the harmful effect of alcohol on the formation of morphological and behavioural changes stigmatising children, which are not always visible from birth, and often take the form characteristic of foetal alcohol syndrome only in schoolchildren. The results of molecular and psychological tests have raised the question as to whether the acceptable limits for blood alcohol content in pregnant women should be established. The toxic effects of alcohol and its metabolites depend not only on the amount consumed, but also on the body condition, style of drinking, and age. Summary: Studies covering 11 European countries have shown that drinking alcohol during pregnancy is more and more common, especially in better-educated women with higher earnings and from larger cities. Therefore, information campaigns that stress the harmfulness of the so-called risky drinking by pregnant women should be targeted primarily at this group.
\end{abstract}

Keywords: alcohol, FAS, pregnancy

Streszczenie Wprowadzenie: Alkohol należy do najsilniejszych używek o działaniu teratogennym. Od lat 60. ubiegłego stulecia prowadzone są akcje informujące o jego szkodliwości oraz propagujące rezygnację z picia, zwłaszcza przez kobiety w ciąży. Cele pracy obejmują dokonanie przeglądu piśmiennictwa poświęconego badaniom nad spożywaniem alkoholu przez kobiety w ciąży i poznanie ich wiedzy na temat szkodliwego wpływu etanolu na ich zdrowie, a także zdrowie ich jeszcze nienarodzonych dzieci. Artykuł zawiera również ocenę akcji społecznych poświęconych informowaniu tej grupy kobiet o szkodliwości picia. Opis stanu wiedzy: Przeprowadzony przegląd jednoznacznie potwierdził dane o szkodliwym wpływie alkoholu na powstawanie stygmatyzujących dzieci zmian morfologicznych i behawioralnych, które nie zawsze są dostrzegalne już od chwili narodzin, często przyjmując postać charakterystyczną dla alkoholowego zespołu płodowego dopiero u dzieci w wieku szkolnym. Wyniki badań molekularnych i psychologicznych nasuwają pytanie, czy należy tworzyć dopuszczalne granice zawartości alkoholu we krwi u kobiet w ciąży. Toksyczne efekty działania alkoholu i jego metabolitów są zależne nie tylko od spożywanych ilości, lecz także od kondycji organizmu, sposobu picia oraz wieku. Podsumowanie: Badania obejmujące swoim zasięgiem 11 krajów Europy wykazały, że w czasie ciąży alkohol piją coraz chętniej zwłaszcza kobiety lepiej wykształcone, o wyższych dochodach i z większych miast. Dlatego akcje informacyjne, które podkreślają szkodliwość tzw. ryzykownego picia alkoholu przez ciężarne, powinny być kierowane przede wszystkim do tej grupy kobiet.

Słowa kluczowe: alkohol, FAS, ciąża 


\section{INTRODUCTION}

$\mathrm{D}$ rinking beer and wine was practiced and described already during ancient times. The first issues arising from alcohol consumption were described by the Egyptians who forbade it in temples in order to "prevent theft, row and rape"(1,2).

First traces suggesting an understanding of alcohol distillation and the ability to obtain high-percentage drinks were found in Alexandria in the $1^{\text {st }}$ century CE. This knowledge was shared by the Greeks, who sent the alcohol obtained in this way to Rome, from where it spread to many other countries. In the Middle Ages, alcoholic beverages were drunk more often than the bad quality water. Biologically contaminated water was indeed the cause of the epidemic of many infectious diseases decimating the population.

In Poland, the first written records of vodka were found in 1405 in court files in Sandomierz. In 1534, Stefan Falimirz, in his encyclopaedia About Herbs and Their Power, listed 72 types of herbal vodkas, and recommended their consumption for various diseases ${ }^{(3)}$.

Over the centuries, numerous harmful effects of alcohol consumption have been reported. Aristotle taught: "Foolish, intoxicated, impulsive women often give birth in their own image"(4). Alcohol consumption of the mother during pregnancy strongly influences the child in utero, and has a lasting influence on its physical characteristics and psyche. Foetal alcohol syndrome (FAS) is a set of features of alcohol-induced damage in a child. Efforts to eliminate this pathology have formed the basis for announcing the World FAS Day, which aims at reminding young people and future parents about the dire consequences of drinking alcohol immediately before and during pregnancy. The First World FAS Day was established in Auckland, New Zealand on September 9, 1999 at 9:09 am. As of that date, every year, on September 9, we celebrate the World FAS Day under the slogan Choose 9 months of alcohol-free pregnancy! ${ }^{(5)}$.

According to the World Health Organization (WHO), drinking alcohol ranks third among the world's health risks, after smoking and high blood pressure. It is directly related to over 60 diseases and many types of injuries. Alcoholic beverages are consumed by 2.3 billion people worldwide, with numbers tending to rise. Alcohol causes 2.3 million deaths a year. It is the most commonly used drug ${ }^{(6)}$.
Europe has the highest level of alcohol consumption. For each inhabitant, there are 11 litres of pure ethanol per year. In Poland, recorded alcohol consumption per capita is approximately 9 litres. There are approx. 800,000 people addicted to alcohol. Alcohol is most often consumed by young people aged 20-29, which is the period most favourable for procreation. More than $87 \%$ of adolescents aged $15-16$ and more than 95\% aged 17-18 report drinking alcohol ${ }^{(6,7)}$.

Each alcoholic drink contains pure ethyl alcohol in various concentrations. Alcohol consumption is defined taking into account diverse ethanol content, as: standard alcohol dose, standard alcohol portion or standard alcohol unit (SAU), which corresponds to $10 \mathrm{~g}$ or $12.5 \mathrm{~mL}$ of pure ethyl alcohol (ethanol). In European countries, the standard alcohol portion is $25 \mathrm{~mL}$ of pure $40 \%$ vodka, $200 \mathrm{~mL}$ of $5 \%$ beer or $100 \mathrm{~mL}$ of $12 \%$ wine $^{(6)}$.

\section{ALCOHOL USE DURING PREGNANCY}

The healthy development of the foetus depends on the lifestyle and proper diet of the pregnant woman. The factors that influence the health of a newborn vary and are more dependent on the woman's lifestyle during pregnancy. In Poland, as in other developed countries, despite numerous appeals from health care practitioners pregnant women still reach for various stimulants. Apart from tobacco, alcohol is one of the most common stimulants used ${ }^{(8)}$.

Drinking alcohol during pregnancy was assessed by the health report of the State Sanitary Inspection for 2017. The results reveal that Polish women are consuming less and less alcohol during pregnancy - there was a decrease from $10.1 \%$ of those who drink with varying frequency during pregnancy in 2012 to $4.84 \%$ in 2017. In 2012, pregnant women most often drank red wine (44.9\%) and beer (30.3\%), similarly as in 2017 , although they consumed slightly less red wine (43.98\%) and more beer $(31.18 \%)^{(8,9)}$. The frequency of women's alcohol consumption before and during pregnancy in Poland in 2017 is presented in Tab. 1. During pregnancy, women who were in informal relationships $(7.1 \%)$ consumed the most alcohol, followed by respondents with middle school (9.48\%) and elementary $(8.45 \%)$ education, women living in average living conditions $(7.4 \%)$, and women who were learning or studying (8.39\%). Only $32.38 \%$ of pre-pregnancy drinkers discontinued alcohol consumption during pregnancy. The remaining

\begin{tabular}{|c|c|c|c|c|}
\hline \multicolumn{5}{|c|}{ Alcohol use by women before pregnancy in Poland in 2017 } \\
\hline Has never had an alcoholic drink & Once a month & $\mathbf{2 - 4}$ times a month & $\mathbf{2 - 3}$ times a week & At least 4 times a week \\
\hline 2,161 & 792 & 373 & 94 & 21 \\
\hline $62.82 \%$ & $23.04 \%$ & $10.81 \%$ & $2.72 \%$ & $0.61 \%$ \\
\hline \multicolumn{7}{|c|}{ Alcohol use by women during pregnancy in Poland in 2017 } \\
\hline $95.18 \%$ & 138 & 16 & 5 & 7 \\
\hline
\end{tabular}

Tab. 1. Frequency of alcohol use by women before and during pregnancy in Poland in 2017 according to the report "Zachowania zdrowotne kobiet $w$ ciąży" ["Maternal health behaviors during pregnancy"] ${ }^{(9)}$ 
respondents continued to drink alcohol, even though they were aware of the consequences during pregnancy. When assessing the relationship between the knowledge of pregnant women on the harmfulness of alcohol for the mother and the child and alcohol consumption during pregnancy, it can be said that the less frequently women consume alcohol, the higher their assessment of the risk associated with drinking it $^{(9)}$.

There is no limit on the dose of alcohol consumed by pregnant women, below which its consumption is certainly safe, and above which it is always harmful. There are negative effects for children both when consuming $14 \mathrm{~g}$ of ethyl alcohol per day by pregnant women or $20 \mathrm{~g}$ per week. Harm to the unborn child may occur at any stage of pregnancy. One "binge" in the first weeks of pregnancy may lead to consequences in the form of characteristic damage and FAS, and changes in the appearance of the baby's face and psyche ${ }^{(10,11)}$. Alcohol is a highly toxic and psychoactive substance. National experts unanimously recommend complete abstinence during pregnancy. Similar recommendations apply in the United States. In contrast, the United Kingdom and Denmark agree that during pregnancy it is recommended to "avoid alcohol as much as possible or limit consumption to one unit a day" $(12,13)$.

A study published in 2017, based on a meta-analysis of 24 cohort and 2 experimental studies of alcohol consumption in pregnant women, found that alcohol usage during pregnancy is "potentially harmful." Although the authors draw quite mild conclusions that "it is better for women to avoid alcohol during pregnancy," in the United Kingdom, where drinking is very popular among pregnant women, the Royal College of Obstetricians and Gynaecologists recommends completely eliminating alcohol consumption during pregnancy ${ }^{(13,14)}$.

The Australian Longitudinal Study on Women's Health (ALSWH), which covered 1,969 women, aimed to estimate the likelihood of alcohol consumption during pregnancy by women who drank before pregnancy. It has been shown that most women who consume alcohol before pregnancy will continue to drink throughout it, even though health care guidelines promote abstinence. Of the 1,969 previously drinking women, $82 \%$ continued to drink alcohol during pregnancy, although they tried to somewhat limit that amount. As many as $77 \%$ of these women drank one or two alcoholic beverages a day, and $90 \%$ drank no more than once or twice a week. Women who drank alcohol once a week before pregnancy were $50 \%$ more likely to drink during pregnancy compared with those who drank less than once a week. On the other hand, women who drank to the effect of alcohol intoxication before pregnancy were more than twice as likely to continue using alcohol during pregnancy. Overall, 1/3 of the 1,969 respondents drank alcohol during pregnancy ${ }^{(15)}$.

The result of this study prompted Food Standards Australia New Zealand (FSANZ), a governmental organisation at the
Australian Government Department of Health, to propose that liquor bottles display information aimed at pregnant women in the form of a graphics showing a drinking pregnant woman and red text: "Health Warning: Any amount of alcohol can harm your baby." The idea was accepted by public health activists, but the alcohol lobby immediately launched an offensive against placing such mandatory labelling on bottles, explaining this objection by the high costs of implementing the concept, which would amount to 600 million dollars ${ }^{(16,17)}$.

Many companies in the alcohol industry are also conspiring against pregnant women by encouraging and persuading that "small doses of alcohol are not harmful" for them and their babies. For example, the manufacturer of Bacardi reports that drinking alcohol during pregnancy represents "some risk," but at the same time emphasizes that these are "completely individual reactions." Such information may create doubts among pregnant women and resignation from abstinence during pregnancy ${ }^{(18)}$.

Research by the State Agency for the Prevention of AlcoholRelated Problems (PARPA) conducted in Poland in 2005 and 2008 revealed that over half of the respondents were aware of the negative impact of alcohol drinking on the foetus. At the same time, over $30 \%$ of the surveyed women confirmed that they consumed alcohol at the procreative age, i.e. between the ages of 18 and 40 , while $17 \%$ indicated that they also consumed alcohol during pregnancy. Younger Polish women (19\%) with a higher education (33\%) as well as women who declare consuming more than 6 litres of pure alcohol per year (57\%) are the most common drinkers. Among women who drink during pregnancy, $0.4 \%$ declared that they consumed alcohol every day, while $0.8 \%$ several times a month ${ }^{(11,19)}$.

A study on pregnant women from Europe, conducted online in 2017 by Ann-Charlotte Mårdby et al. from the University of Gothenburg, included 7,905 pregnant women from 11 European countries: Great Britain, Russia, Switzerland, Serbia, Italy, Finland, Croatia, France, Poland, Sweden and Norway. The aim of the research was to find out how often pregnant women drink alcohol. As a model measure of consumed alcohol, the authors assumed a standard dose of alcohol corresponding to $12 \mathrm{~g}$ of $100 \%$ alcohol, which corresponds to a small can or bottle $(330 \mathrm{~mL})$ of beer or cider, a glass $(120 \mathrm{~mL})$ of wine or one glass $(40 \mathrm{~mL})$ of vodka or liqueur. A surprising conclusion was that it is better-educated women who drink more in all the countries surveyed, which is in line with previous PARPA research. Furthermore, it has been found that:

- the most frequent European drinkers during pregnancy are the British (28.5\%), Russian (26.5\%) and Swiss (20.9\%);

- the lest frequent pregnant drinkers are women from Norway (4.1\%), Sweden (7.2\%) and Poland (9.7\%);

- on average in Europe, $16 \%$ of women use alcoholic beverages during pregnancy, and $38.9 \%$ of them drink at least 1 unit of alcohol a month; 
- usually older women and women with higher education consume more alcohol;

- Italian women are the most regular alcohol drinkers (26\%); they consume at least 1 unit a week; $56.6 \%$ of Italian women who admit to drinking alcohol during pregnancy drink 1 unit a month.

In the study in question, $1.5 \%$ of Polish women who drank alcohol during pregnancy admitted to consuming more than 2 units of alcohol during the entire pregnancy, $4.5 \%-$ 1-2 units a week, and 20\% - 1-4 units monthly. Over 70\% of respondents said that they had no more than 1-2 drinks during their pregnancy.

The results of this analysis are extremely alarming, as they show that each year as many as 700,000 children born in the 11 surveyed European countries may be exposed to the toxic effects of alcohol in utero ${ }^{(20,21)}$.

Women who consume alcohol during pregnancy very often do not admit to such behaviour, therefore the issue of alcohol consumption in this group is still underestimated. Experts from Poland and other countries believe that the number of pregnant drinkers is greater than it appears from official data.

Drinking alcohol, especially "occasionally," has currently become very fashionable, mainly among very young women, which can impair their fertility. According to research carried out in 2005 by PBS at the request of PARPA and a similar study from 2008, women aware of the negative impact of drinking alcohol during pregnancy accounted for $87 \%$ and $95 \%$ of the respondents, respectively. Although in comparison with 2005, in 2008 alcohol consumption in the population of women who have ever been pregnant decreased from $16.5 \%$ to $12 \%$, unfortunately its frequency has almost doubled among $1 / 3$ of educated pregnant women from $17.8 \%$ to $35 \%^{(11,22,23)}$.

In a study conducted by Sioda, $30 \%$ of women indicated that they consumed alcohol at the procreative age, i.e. between the ages of 18 and 40 , where $17 \%$ confirmed alcohol usage also during pregnancy. Among them, $0.4 \%$ declared that they drank daily, while $0.8 \%$ only a few times a month ${ }^{(19)}$.

\section{HEALTH IMPLICATIONS OF ALCOHOL CONSUMPTION FOR WOMEN}

In the prepubertal period, alcohol causes a decrease in the secretion of lutropin and growth hormone in women, and destabilizes the functioning of the reproductive system by disturbing the menstrual cycle, accelerating the menopausal period, and infertility ${ }^{(6,10)}$. The alcoholic drink that women choose most often is wine. According to a small group of researchers, red wine has a positive effect on the human body - they believe that the flavonoids which it contains, i.e. strong antioxidants: resveratrol and quercetin, have a bactericidal effect and destroy the Helicobacter pylori bacteria that reside in the stomach. This reaction occurs when the
The negative health effects of drinking wine are more important than its bactericidal effects. Women experience the negative biological, psychological and social implications of alcohol abuse much faster and more often than men. The rapid accumulation of the negative effects of alcohol abuse in women is referred to as "telescoping." Alcohol causes faster damage to the peripheral and central nervous systems in women, which contributes to the increased incidence of neurological and mental diseases. Internal organs are also damaged, especially the liver and blood vessels ${ }^{(25)}$. Drinking before the age of 30 increases the risk of breast cancer $^{(26)}$. Alcohol abuse can result in epigenetic damage to the genetic material in preovulatory oocytes ${ }^{(27)}$. Therefore, drinking alcohol by women at a young age, i.e. at 18-39, in the period of the highest consumption among Polish women, may limit their reproductive potential ${ }^{(12)}$.

Alcohol consumed by pregnant women increases the levels of prostaglandins which cause preterm labour ${ }^{(27)}$.

The effect of alcohol depends on the dose and frequency of consumption. Drinking alcohol, even in moderate amounts, increases the risk of endometriosis and ovulation disorders, leading to infertility. Alcohol consumption by women of childbearing age causes reproductive failure, frequent miscarriages, and preterm birth ${ }^{(6,19)}$. Prematurity is not only a problem of the parents and the child, but it is also a very serious social issue.

It is assumed that spontaneous abortion is induced by a blood alcohol concentration in the mother of approximately $200 \mathrm{mg} / \mathrm{dL}$, which is achieved after drinking $72 \mathrm{~g}$ of pure ethanol. This amount is contained in about 6 drinks, consumed daily for several days a week ${ }^{(19,28)}$.

The effects of long-term alcohol abuse include malnutrition, malabsorption, and dehydration ${ }^{(25)}$. Women who drink are more frequently diagnosed with hepatotoxicity which leads to inflammation and cirrhosis, and in turn increases mortality ${ }^{(24)}$. Altered sexual behaviour under the influence of alcohol increases the incidence of sexually transmitted diseases and the number of unplanned pregnancies ${ }^{(29)}$.

Alcohol increases the concentration of free radicals in the body cells by inhibiting the formation of enzymes that are involved in the metabolism of catalase and superoxide dismutase. The increase in the concentration of pro-inflammatory cytokines, especially interleukin 1 (IL-1), induces the release of nitrogen-centred free radicals. These substances damage cell membranes, leading to apoptosis. Within trophoblasts, this increases the risk of miscarriage and placental insufficiency. As a result, the group of women who drink alcohol during pregnancy is more often found with intrauterine growth restriction, premature placental abruption, preterm births, foetal hypoxia, and intrauterine foetal death $^{(10,30)}$. The detrimental impact of alcohol on the health of children in the prenatal period has been known in Poland for a long time. The official position on this subject was presented by PARPA in $2005^{(22)}$. FAS has been recognised as an extreme outcome of foetal damage from alcohol consumption during pregnancy. Although the consequences of 
drinking alcohol by pregnant women are quite well known in the societies of most countries around the world (99\%), not every woman is able to completely abandon the consumption of alcohol during pregnancy. Polish studies show that although $74-98.6 \%$ of the surveyed women are aware of the harmful effects of alcohol use during pregnancy, $1 / 3$ still consume it during this period ${ }^{(6,8,10,25)}$.

In 2012, Wojtyła et al. examined a group of 8,237 pregnant Polish women and found that over $13 \%$ occasionally consumed alcohol in early pregnancy, while $85 \%$ confirmed complete abstinence at that time ${ }^{(31)}$.

\section{ALCOHOL USE IN PREGNANCY AND ITS HEALTH IMPLICATIONS ON THE CHILD}

Alcohol is the most common and easily available teratogen ${ }^{(32)}$. The child is affected: directly - by damaging and killing the developing cells of the foetus - and indirectly - by impairing the function of the placenta and/or influencing certain stages of biochemical changes responsible for foetal development. These changes are induced by even a small amount of alcohol in alcoholic beverages consumed by pregnant women, either occasionally or every day. Alcohol and its much more toxic metabolite called acetaldehyde pass through the placenta into the blood of the foetus and into the foetal brain tissue, and damage it. Consumption by the mother of each dose of ethanol, even on a one-off basis, results in the same concentration in the foetal blood after 30-60 minutes. The concentrations of ethanol and acetaldehyde depend on the rate of their metabolism by dehydrogenases in the liver. The toxic effect of alcohol on the foetus is exacerbated by hepatic immaturity, which metabolises alcohol twice as long ${ }^{(33)}$. The teratogenic effect of alcohol damages the embryo and the foetus, causing morphological and cognitive defects that limit the child's future social functioning. The molecular mechanism of the damaging effect of alcohol on foetal tissues involves, among others, its participation in transmethylation reactions of nucleic acids in which it is a donor of methyl residues. The resulting changes in the DNA of neural tube cells lead to a reduction in the expression of genes regulating the development of neurons and their growth factors. This, in turn, inhibits cell division and delays cell maturation. The end result is a reduction in the total mass and volume of the foetal central nervous system and an increase in the population of undifferentiated neurons within it ${ }^{(10)}$.

In Poland, each year there are approx. 10,000 newborns with low birth weight due to alcohol abuse during pregnancy ${ }^{(6)}$. Drinking alcohol, especially in pregnant addicts, leads to nutritional deficiencies and neurodevelopmental disorders as a result of folate, choline and vitamin A deficiencies, which disturbs the structure and functioning of the foetal central nervous system. It has been shown that children whose mothers drink alcohol during pregnancy have a lowered intelligence quotient (IQ) of even $70-89^{(34)}$. The group of pregnant drinkers had a lower concentration of protein in the placenta, reduced iron transport, lower vitamin $B_{12}$ and polyunsaturated fatty acids, and disorders of glucose and cholesterol metabolism ${ }^{(35)}$.

The damaging effects of alcohol on the foetus occur from the very beginning of pregnancy, and the effects depend on the pregnancy stage. Alcohol consumed in weeks 3.5-6.5 of pregnancy induces congenital heart defects, in weeks 3-16central nervous system damage, in weeks 4-6 - limb damage, in weeks 4-8 - face and eye malformation, in weeks 4-7 - nose deformities, in weeks 7-8 - dental anomalies, in weeks 5-12 - ear malformation, in weeks 7-12 - palate malformation. During the period from week 8, alcohol may cause death of the embryo or miscarriage. Alcohol abuse in the first trimester has more serious consequences than the use of marijuana, cocaine or heroin ${ }^{(36)}$.

Consumption of alcohol in the second trimester increases the frequency of miscarriages, causes disturbances in the development of the central nervous system, damages to the muscles, skeleton, skin, liver, and endocrine glands.

Drinking alcohol in the third trimester of pregnancy may inhibit intrauterine growth of the foetus, induce preterm labour, placental pathology and neuropsychosomatic disorders. Ethanol also impairs foetal lung maturity through its toxic effects on type II and III pneumocytes and a reduction in alveolar surfactant concentration. By disrupting the functions of macrophages, $\mathrm{B}$ and $\mathrm{T}$ lymphocytes, it causes autoimmune disorders of the foetus, and consequently increases the risk of infection in the newborn by 2.5 times in the case of occasional consumption and by 4 times in excessive consumption $^{(10,33,36)}$.

The maximum adverse effect of alcohol consumption in a pregnant woman is the foetal alcohol syndrome (FAS) and its milder form, the foetal alcohol effect (FAE). The consequences of alcohol consumption by women during pregnancy were first described in 1968 by the French paediatrician Paul Lemoine, who characterised the clinical picture of 127 children from 62 families of alcoholics suffering from a set of conditions, which was initially named after him as "Lemoine's syndrome." Five years later, American doctors David Smith and Kenneth Jones described a similar syndrome of alcohol damage in the children of mothers who drink alcohol during pregnancy, which they termed FAS. A child with FAS has characteristic facial features: lack of a nasolabial groove, short palpebral fissures and a thin upper lip, additionally strabismus, underdevelopment of the nails and a short neck. Children with FAS are delayed in psychophysical development ${ }^{(3)}$. There are no exact studies on the incidence of FAS. It is assumed that 3/1,000 live births in Poland may be affected, which is twice the number of children with Down syndrome (1/700 live births, i.e. FAS $-21 / 7,000$ live births vs. Down syndrome $-10 / 7,000$ live births).

Various developmental disorders classified as FAE are ten times more common. It is estimated that negative consequences of foetal alcohol exposure may occur in $1 \%$ of all newborns. In Europe, the prevalence of FAS is 1.7-3.3/1,000 births. 
Each year, approximately 2,200 children are born with FAS in Germany, 5,000 in the United States, and more than 6,000 in France and England in total. It is worth adding that these values are believed to be underestimated. In Poland, each year about 900 children are born with full-blown FAS, and a ten times larger group of children suffer from other types of disorders caused by the influence of alcohol consumed by their mothers during pregnancy, described as FASD (foetal alcohol spectrum disorder), which includes only some of the FAS symptoms, among others, alcohol-related birth defects and alcohol-related neurologic disorders. Most cases of FASD remain undiagnosed or misdiagnosed. FAS is the root cause of mental illness. The worldwide prevalence of FAS is estimated at approx. 3-9/1,000 live births ${ }^{(32)}$.

Due to the variety of changes that occur in children exposed to alcohol in utero, deficits in their development often become visible only at the beginning of school education. Children with undiagnosed FASD are often initially diagnosed with attention-deficit/hyperactivity disorder (ADHD) because of the numerous similarities between these two dysfunctions. Children with FASD face more difficulties in interpreting the social context than children with ADHD, which translates into more intense behaviour problems. Children with FASD are also more often diagnosed with mental disorders than children with ADHD. FASD and ADHD are relatively similar in the behavioural aspect, especially in terms of difficulty concentrating, excessive impulsiveness, and hyperactivity ${ }^{(37,38)}$.

\section{DISCUSSION}

Currently, young people exhibit the so-called risky model of drinking alcohol that has no visible physical or mental effects. Women who drink alcohol during pregnancy assess that it is safe both for themselves and for the baby. Unfortunately, such alcohol usage turns into harmful drinking quite quickly and imperceptibly, causing negative health effects for the adults and their unborn offspring. Preventive healthcare should consist in providing information about the harmfulness of alcohol consumption during pregnancy, and above all presenting images of affected children, mutilated by their parents' ignorance and lack of responsibility. Compared to men, women drink alone more often. They are more socially stigmatised for alcohol abuse, which is why some hide their addiction. Women themselves believe that their addiction is more forbidden, shameful, repulsive and less socially acceptable than male alcoholism. Younger women are more heavily burdened with a sense of stigma and rejection ${ }^{(39,40)}$. For these reasons, the number of women who drink during pregnancy may be underestimated ${ }^{(41)}$. There are many risk factors for addiction in women. The most common are environmental burdens such as: lack of social support, alcoholism in the family, living with an alcoholic spouse, and age (very young women use alcohol more often than mature women). Scientific research shows that wom-
Most women who consume alcohol during pregnancy are addicts, but this is not always the case. In this respect, two patterns of alcohol consumption by pregnant women can be distinguished, i.e. occasional drinking and alcohol abuse. Alcohol abuse during pregnancy is correlated with smoking, pre-pregnancy psychoactive substance use and lower financial status ${ }^{(43)}$. Compared to men, alcohol dependence in women more often coincides with depression, anxiety disorders, and posttraumatic disorders. Women use alcohol as a means of relieving tension. Hormonal changes during pregnancy can cause mood swings. The birth waiting period is a time of many changes in life related to economic, professional, organizational, family, and emotional challenges. The expectant mother often has to limit or abandon her professional career, which in turn may deteriorate her financial situation, be associated with the need to reorganize or give up her career and aspirations, or experiencing a sense of losing one's own autonomy. Motherhood not only means positive experiences of love and bond, but also fears concerning the child (especially before birth), a new liability and new responsibilities. These changes affect not only the mother, but the whole family, which is an additional source of stress. The pregnant woman experiences a change in identity - she becomes a mother, connected with her child by a strong emotional and biological bond. This requires a reformulation of one's own image, changes in the perception of one's role and recognition of one's limitations. Sometimes pregnancy is not completely acceptable to a woman due to personal or family problems or changes in her body. These phenomena become a source of additional stress and risk factors for drinking alcohol.

There are many barriers for women to use drug addiction programs, which are driven by economic, social and individual factors. These barriers concern accessibility (e.g. the need to attend meetings in the evening hours), the need to reconcile therapy with running a home, raising children, opposition from the social environment (denial of addiction and the need for treatment) due to fear of stigmatisation, lack of social support (spouses are more likely to leave drinking women, while female partners stay with the drinking man), fear of negative social judgment (a drinking woman is subject to moral evaluation more often than a man - her behaviour is considered pathological, she is ascribed promiscuity and considered a degenerate person, unfit to be a mother). For these reasons, it is postulated that the treatment should be conducted in female therapeutic groups, the availability of which is still insufficient ${ }^{(40,44)}$. Alcohol is a drug and a substance whose use depends only on the will of the person reaching for it, therefore, it should be considered whether, if pregnant women had been fully informed about the irreversible damage to their children's health, while also exposing themselves to health and educational problems, they would still drink alcohol during pregnancy. It happens that campaigns promoting a healthy lifestyle indicate the actual consequences of alcohol consumption as possible, but not always certain. Such presentation of medical data is a good 
explanation for drinking alcohol, even during pregnancy. Therapeutic programs should take into account the specificity of women's problems and be centred around comprehensive help: medical, psychotherapeutic, family counselling, social and parental competence training, education, career support and social support ${ }^{(41)}$. Analysis of alcohol dependence treatment programs for pregnant women has shown that interventions based on confrontation, judgment, discrediting and controlling deprive pregnant women of selfconfidence. On the other hand, positive effects were allowed with programs that were based on the pursuit of healing, acceptance, taking into account the awareness of stigmatization and the feeling of guilt and shame of pregnant women abusing alcohol, based on positive communication, activating the patients, and covering them with integrated care ${ }^{(44)}$.

\section{CONCLUSION}

The risk of drinking alcohol during pregnancy increases the more alcohol consumption is part of an earlier lifestyle (even in non-addicted women).

Women who are addicted to alcohol are characterized by a strong sense of guilt and shame ${ }^{(45,46)}$. Psychological variables that enhance the effectiveness of fighting addiction among women are: improving the sense of self-efficacy in addicted women, strengthening arguments against reaching for alcohol, and increasing self-satisfaction and concern for one's health ${ }^{(40)}$. Pregnant women see concern for the health of the baby as a strong motivator to stop drinking alcohol, but therapeutic and educational programs are required to maintain this abstinence throughout pregnancy.

\section{Conflict of interest}

The authors have no financial or personal connections to declare with other persons or organisations that could adversely affect the content of the publication and claim the right to this publication.

\section{References}

1. Froń R: Kobiety i piwo. Paragraf w kieliszku. 2015. Available from: http://paragrafwkieliszku.pl/kobiety-i-piwo/ [cited: 15 January 2020].

2. Stępień M: Kodeks Hammurabiego. Wydawnictwo Alfa, Warszawa 2000.

3. Forsyth M: Krótka historia pijaństwa. Na rauszu przez wieki. Jak, dlaczego, gdzie i kiedy człowiek popijał. Wydawnictwo Dolnośląskie, Wrocław 2018.

4. Calhoun F, Warren K: Fetal alcohol syndrome: historical perspectives. Neurosci Biobehav Rev 2007; 31: 168-171.

5. Swiatowy dzień FAS. Puls Medycyny 2019. Available from: https://pulsmedycyny.pl/swiatowy-dzien-fas-969858 [cited: 15 January 2020].

6. Pawłowska-Muc AK, Łepecka-Klusek C, Kozak-Pilewska AB et al.: Używki w ciąży - alkohol. J Educ Health Sport 2015; 5: 385-394.

7. Abramowicz M, Brosz M, Bykowska-Godlewska B et al.: Wzorce konsumpcji alkoholu. Studium socjologiczne. Wydawnictwo Zakładu Realizacji Badań Społecznych Q\&Q, Kawle Dolne 2018.
8. Żuralska R, Kuzepska M, Mziray M: Alkohol i ciąża. Wstępne badania opinii kobiet na temat spożywania alkoholu w okresie ciąży. Probl Pielęg 2011; 19: 533-537.

9. Raport $\mathrm{z}$ badania „Zachowania zdrowotne kobiet w ciąży”. Państwowa Inspekcja Sanitarna, ProVision Solutions, Warszawa 2017. Available from: https://gis.gov.pl/wp-content/ uploads/2018/04/Zachowania-zdrowotne-kobiet-wci\%C4\%85\%C5\%BCy-alkohol-i-papierosy.-Raport-2017-1.pdf [cited: 17 January 2020].

10. Okulicz-Kozaryn K, Stanisławska A, Opuchlik K et al.: Zapobieganie spektrum płodowych zaburzeń alkoholowych (FASD). Wczesne rozpoznanie ryzyka i krótka interwencja lekarska. Państwowa Agencja Rozwiązywania Problemów Alkoholowych, Warszawa 2018. Available from: https://www.ciazabezalkoholu.pl/ images/file/ZAPOBIEGANIE_FASD.pdf [cited: 17 January 2020].

11. Strycharz-Dudziak M, Nakonieczna-Rudnicka M, Bachanek $T$ et al.: Telewizja i internet jako źródła wiedzy kobiet o wpływie palenia papierosów, spożywania alkoholu i napojów energetyzujących na stan zdrowia. Przegl Lek 2014; 71: 624-628.

12. Vetulani J: Alkoholizm i neurobiologia farmakoterapii alkoholizmu. Wszechświat 2013; 114; 24-30.

13. Royal College of Obstetricians and Gynaecologists. Wpływ alkoholu na przebieg ciąży. Aktualne (2006 r.) Med Prakt Ginekol Położ 2007; 3: 37-45.

14. Royal College of Obstetricians and Gynaecologists: RCOG statement on new research on drinking during pregnancy. 2017. Available from: https://www.rcog.org.uk/en/news/rcog-statement-on-new-research-on-drinking-during-pregnancy [cited: 20 January 2020].

15. Anderson AE, Hure AJ, Forder P et al.: Predictors of antenatal alcohol use among Australian women: a prospective cohort study. BJOG 2013; 120: 1366-1374.

16. McCauley D: Alcohol lobby says new pregnancy warning labels 'too expensive. The Sydney Morning Herald 2019. Available from: https://www.smh.com.au/politics/federal/alcohol-lobbysays-new-pregnancy-warning-labels-too-expensive20191127-p53elf.html [cited: 20 January 2020].

17. Wyka J, Misiarz M, Malczyk E et al.: Ocena spożycia alkoholu, kawy i palenia papierosów wśród kobiet w ciąży. Bromat Chem Toksykol 2015; 48: 578-582.

18. Campbell D: Alcohol industry 'puts pregnant women at risk', researchers say. The Guardian 2019. Available from: https:// www.theguardian.com/society/2019/oct/14/alcohol-industrypregnant-women-research-health [cited: 21 January 2020].

19. Sioda TW: Wpływ alkoholu na prokreację i wczesny okres macierzyństwa. Pediatr Pol 2009; 84: 344-361.

20. Mårdby AC, Lupattelli A, Hensing G et al.: Consumption of alcohol during pregnancy - a multinational European study. Women Birth 2017; 30: e207-e213.

21. Piotrowska A: Złe zwyczaje ciężarnych Europejek. 2017. Available from: https://zdrowie.pap.pl/strefa-intymna/male-jasneciezarnych-europejek [cited: 21 January 2020].

22. Państwowa Agencja Rozwiązywania Problemów Alkoholowych: Jak zmieniają się postawy kobiet wokół picia alkoholu w ciąży? Available from: https://www.parpa.pl/index.php/ciaza-bez-alkoholu/badania [cited: 27 July 2021].

23. Wojnar M, Fudała M, Brzózka K: Zachowania zdrowotne kobiet w ciąży. Picie alkoholu. PARPA. Posiedzenie Rady Naukowej przy Ministrze Zdrowia, 24.03.2010.

24. Szymczak A, Niśkiewicz I, Krela-Kaźmierczak I et al.: Wpływ alkoholu na wybrane schorzenia przewodu pokarmowego. Now Lek 2009; 78: 222-227.

25. Żukiewicz-Sobczak W, Paprzycki P: Raport „Zachowania zdrowotne kobiet w ciąży". Instytut Medycyny Wsi im. Witolda Chodźki, Lublin 2013.

26. Kozakiewicz B, Chądzyńska M, Czetwertyńska M et al.: Modifiable risk factors of breast cancer in young women - Polish experiences and literature review. Eur J Pharm Med Res 2019; 6: 595-603.

27. Cook JL, Randall CL: Ethanol and parturition: a role for prostaglandins. Prostaglandins Leukot Essent Fatty Acids 1998; 58: 135-142. 
28. Łepecka-Klusek C: Zdrowie i płodność kobiety. In: Łepecka-Klusek C (ed.): Pielęgniarstwo we współczesnym położnictwie i ginekologii. PZWL, Warszawa 2010: 1-44.

29. Machaj A, Roszak M, Stankowska I: Ryzykowne zachowania seksualne kobiet w okresie prokreacyjnym. Now Lek 2010; 79: 22-31.

30. Mamluk L, Edwards HB, Savović J et al.: Low alcohol consumption and pregnancy and childhood outcomes: time to change guidelines indicating apparently 'safe' levels of alcohol during pregnancy? A systematic review and meta-analyses. BMJ Open 2017; 7: e015410.

31. Wojtyła A, Kapka-Skrzypczak L, Diatczyk J et al.: Alcohol-related developmental origin of adult health - population studies in Poland among mothers and newborns (2010-2012). Ann Agric Environ Med 2012; 19: 365-377.

32. Dannaway DC, Mulvihill JJ: Poalkoholowe uszkodzenie płodu. Pediatr Dypl 2011; 15: 55-63.

33. Warzycha J, Baryła M, Halkiewicz $M$ et al.: Wpływ alkoholu na rozwój dziecka - współczesne poglądy. Post Neonatol 2013; 19: 64-68.

34. Marek M: Spożywanie alkoholu przez kobiety w czasie ciąży zagrożeniem dla rozwoju dziecka. Studia Socialia Cracoviensia 2013; 2: 145-153.

35. Memo L, Gnoato E, Caminiti S et al.: Fetal alcohol spectrum disorders and fetal alcohol syndrome: the state of the art and new diagnostic tools. Early Hum Dev 2013; 89 Suppl 1: S40-S43.

36. Dębski R, Paszkowski T, Wielgoś M et al.: Stanowisko Grupy Ekspertów na temat wpływu alkoholu na ciążę: stan wiedzy na 2014 rok. Gin Pol Med Project 2014; 2: 66-78.

37. Preidt R: Fetal alcohol disorders often misdiagnosed as ADHD. 2009. Available from: https://abcnews.go.com/Health/Healthday/story?id=8114830\&page [cited: 22 January 2020].
38. Banach M, Matejek J: „W trosce o zdrowie dziecka i twoje”. Płodowy Zespół Alkoholowy (FAS) - kompendium wiedzy. Wydawnictwo «scriptum», Kraków 2016.

39. Gomberg ES: Alcoholic women in treatment: the question of stigma and age. Alcohol Alcohol 1988; 23: 507-514.

40. Juczyński A: Zmiany w trakcie terapii wyznacznikiem utrzymywania abstynencji. Badania kobiet uzależnionych od alkoholu. In: Chodkiewicz J, Gąsior K (eds.): Wybrane zagadnienia psychologii alkoholizmu. Difin, Warszawa 2013: 94-113.

41. Opora R: Charakterystyka zjawiska uzależnienia i nadużywania alkoholu przez kobiety. Resocjalizacja Polska 2012; 3: 317-326.

42. Moskalewicz J: Problemy zdrowia prokreacyjnego związane z konsumpcją alkoholu. In: Raport „Zdrowie kobiet w wieku prokreacyjnym 15-49 lat. Polska 2006”. Program Narodów Zjednoczonych ds. Rozwoju i Ministerstwo Zdrowia, Warszawa 2007: 70-73.

43. McKeague M, Norton S, Canfield M: A review of factors associated with patterns of drinking during pregnancy. Adv Dual Diagn 2020; 13: 6-23.

44. Renbarger KM, Shieh C, Moorman M et al.: Health care encounters of pregnant and postpartum women with substance use disorders. West J Nurs Res 2020; 42: 612-628.

45. Gąsior K: Typy alkoholizmu u kobiet. Alkohol Narkoman 2005; 18: 39-56.

46. Karoll BR: Women and alcohol-use disorders: a review of important knowledge and its implications for social work practitioners. J Soc Work (Lond) 2002; 2: 337-356. 